\title{
A new technique for seeding chondrocytes onto solvent- preserved human meniscus using the chemokinetic effect of recombinant human bone morphogenetic protein-2
}

\author{
Hiroaki Minehara $\cdot$ Ken Urabe $\cdot$ Kouji Naruse • \\ Alexander T. Mehlhorn - Kentaroo Uchida • \\ Norbert P. Südkamp • Moritoshi Itoman
}

Received: 16 December 2009/Accepted: 28 May 2010/Published online: 17 June 2010

(C) The Author(s) 2010. This article is published with open access at Springerlink.com

\begin{abstract}
Many investigators are currently studying the use of decellularized tissue allografts from human cadavers as scaffolds onto which patients' cells could be seeded, or as carriers for genetically engineered cells to aid cell transplantation. However, it is difficult to seed cells onto very dense regular connective tissue which has few interstitial spaces. Here, we discuss the development of a chemotactic cell seeding technique using solvent-preserved human meniscus. A chemokinetic response to recombinant human bone morphogenetic protein-2 (rhBMP-2) was observed in a monolayer culture of primary chondrocytes derived from femoral epiphyseal cartilage of 2-day-old rats. The rhBMP-2 significantly increased their migration upto $10 \mathrm{ng} / \mathrm{ml}$ in a dose-dependent manner. When tested with solvent-preserved human meniscus as a scaffold, which has few interstitial spaces, rhBMP-2 was able to induce chondrocytes to migrate into the meniscus. After a 3-week incubation, newly-formed cartilaginous extracellular matrix was synthesized by migrated chondrocytes throughout the meniscus,
\end{abstract}

H. Minehara · K. Urabe $(\bowtie) \cdot$ K. Naruse ·

K. Uchida $\cdot$ M. Itoman

Department of Orthopaedic Surgery, Kitasato University

School of Medicine, 1-15-1 Kitasato, Sagamihara, Japan

e-mail: kenurabe@med.kitasato-u.ac.jp

A. T. Mehlhorn · N. P. Südkamp

Department of Orthopaedic and Trauma Surgery,

Albert-Ludwig University, Freiburg, Germany down to a depth of $3 \mathrm{~mm}$. These findings demonstrate that rhBMP-2 may be a natural chemokinetic factor in vivo, which induces migration of proliferative chondrocytes into the narrow interfibrous spaces. Our results suggest a potential application of rhBMP-2 for the designed distribution of chondrocytes into a scaffold to be used for tissue engineering.

Keywords BMP-2 - Chondrocytes ·

Cell migration $\cdot$ Chemokinesis

\section{Introduction}

In most tissue engineering approaches, cells are typically isolated from a small biopsy sample and then expanded in culture. These expanded cells are then seeded onto a suitable three-dimensional scaffold and induced to produce a tissue-like structure in vitro. The composites of cells and scaffold are then implanted in vivo into an orthotopic site to repair damaged tissue. The phenotype of a cell-based tissueengineered construct depends on a number of factors, such as the composition, size, porosity and biodegradability of the scaffold, as well as the cell type, cell density, and spatial distribution of the cells within the construct (Langer 2000). The cellularity of the engineered construct depends on the number of cells initially introduced into the construct, on the retention of these cells during the first few hours to days until cell-cell and cell-scaffold interactions have 
been established, and on the mitotic activity of the cells incorporated into the construct (Solchaga et al. 2006). For any given scaffold, the initial seeding influences cell density, retention, and spatial distribution within the scaffold, all of which will eventually affect the function of the construct (Griffon et al. 2005; Holy et al. 2000; Mauck et al. 2002) .

Currently, there are a variety of methods used for seeding cells into a three-dimensional matrix with the aim of achieving uniform cell distribution (Griffon et al. 2005; Solchaga et al. 2006; Thevenot et al. 2008; Timmins et al. 2007; Wendt et al. 2003). In the passive methods of seeding, cells are laid on top of the scaffold and allowed to infiltrate into the scaffold over time (Wendt et al. 2003). The main disadvantage, particularly in the case of thick scaffolds with high degrees of tortuosity, is that the infiltration rates can be very low, resulting in poor loading and uneven distribution of cells within the scaffolds. In the active methods of seeding, an external force is applied to encourage the cells to infiltrate into the porous scaffold (Cimetta et al. 2007; Griffon et al. 2005; Mauck et al. 2002). The nature of the force varies from centrifugal to external pressure gradients, vacuum and compression force (Griffon et al. 2005; Griffon et al. 2005; Thevenot et al. 2008). However, it is difficult to seed cells into high density regular connective tissue which has few interstitial spaces. Here, we discuss the development of a chemotactic cell seeding technique using solvent-preserved human meniscus which has a highly dense collagen structure.

Bone morphogenetic protein (BMP)-2, a member of the transforming growth factor (TGF)- $\beta$ superfamily (Chen et al. 1991a, b; Massague 1992; Sampath et al. 1990; Wozney et al. 1988) plays an important role in the differentiation of mesenchymal cells. Generally, BMP-2 stimulates cell differentiation when the concentration is higher than $100-500 \mathrm{ng} / \mathrm{ml}$ in vitro (Date et al. 2004; Kawasaki et al. 1998; Ryoo et al. 2006; Sekiya et al. 2005). On the other hand, BMP-2 also affects migration of mesenchymal cells, fibroblasts and osteoblasts (Bhardwaj et al. 2001; Fiedler et al. 2002; Lind et al. 1996; Uchida et al. 2007) but the concentration of BMP-2 required for cell migration is lower than that for differentiation. Migratory effects of BMP-2 have also been noted in endothelial cells or smooth muscle cells, but rarely in chondrocytes.
Bhargava et al. (1999) have evaluated the migratory effects of several cytokines including BMP-2 on bovine meniscus cells. The meniscus-derived cells, which may contain chondrocytic cells, were not well characterized in the study. Isolated chondrocytes are easy to irreversibly dedifferentiate in monolayer culture (Mukaida et al. 2005) and therefore, it is unclear whether the cells used by Bhargava et al. (1999) still retained the biological characteristics of meniscus chondrocytes. In addition to the reported effect of BMP-2 on chondrocyte differentiation and cartilage matrix formation (Erickson et al. 1997; Stewart et al. 2004), we considered that investigation of the chemotactic and/or chemokinetic effect of BMP-2 on chondrocytes would be necessary. We also hypothesized that the migratory effect of BMP-2 on chondrocytes could be useful for chondrocyte seeding into solvent-preserved human meniscus.

In this study we used proliferating chondrocytes isolated from the distal epiphysis of 2 day old Wistar rats and evaluated the response of chondrocytes to BMP-2. We also developed a chondrocyte seeding technique into solvent-preserved human meniscus using the migratory response of chondrocytes to BMP-2.

\section{Materials and methods}

Preparation of proliferating chondrocytes

All the procedures involving animals were carried out in accordance with the guidelines of Kitasato University Animal Ethics Committee. Chondrocytes in the distal epiphysis were harvested from 2 day old Wistar rat femora. The distal femora were exposed and adherent soft tissues were stripped. The reserved zone of the epiphysis was removed by dissection. The cartilage fragments containing the reserved zone chondrocytes were washed three times in PBS (Wako) containing antibiotics (streptomycin, penicillin, fungizone (GIBCO-Invitrogen, Carlsbad, CA)) and digested for $4 \mathrm{~h}$ in a $0.3 \%$ solution of Collagenase $\mathrm{P}$ (GIBCO) in PBS in a shaking water bath at $37^{\circ} \mathrm{C}$. The solution containing the isolated cells was filtered through $70-\mu$ mesh and the cells recovered by centrifugation at $1,000 \mathrm{rpm}$ at $4^{\circ} \mathrm{C}$ and resuspended in Ham's F-12 medium (Biochrom AG, Berlin, Germany) containing antibiotics and $10 \%$ FBS at a 
final concentration of $2 \times 10^{5}$ cells $/ \mathrm{ml}$. The isolated cells were used for each experiment immediately after isolation.

Migratory response of chondrocytes to rhBMP-2

Disposable 96-well chemotaxis chambers (Neuro Probe, Gaithersburg, MD) were used (Albini et al. 1987; Uchida et al. 2007). Recombinant hBMP-2 ( $\mathrm{R} \& \mathrm{D}$ systems, Minneapolis, MN) was added to a final concentration of $0.01,0.1,1,10$ or $100 \mathrm{ng} / \mathrm{ml}$ in Dulbecco's modified Eagle's medium (DMEM; Cambrex, Walkersville, MD) containing $1 \%$ antibiotic mixture (GIBCO). Primary proliferating chondrocytes $\left(1 \times 10^{4}\right.$ cells/well $)$ were seeded in Ham's F-12 medium onto the membrane of the chamber set in a 6-well plate. Cell number was standardized using a curve prepared from $0,25,50,100,200,400,800$ and 1,600 cells $/ 50 \mu \mathrm{l}$ solution. The chemotaxis chamber was incubated in $5 \% \mathrm{CO}_{2}$ at $37^{\circ} \mathrm{C}$ for $48 \mathrm{~h}$. Cells were then labelled with $2.5 \mu \mathrm{M}$ Calcein acetoxymethyl ester (AM) after eliminating the non-migrant cells (Uchida et al. 2007) and the fluorescence of each sample was measured by a plate reader (Spectra Fluor Plus, Tecan, Finland).

The chemotactic responses of chondrocytes were tested by checkerboard analysis to determine whether cell migration was due to chemotaxis (i.e., cell migration in response to a concentration gradient) or chemokinesis (i.e., cell migration irrespective of a concentration gradient) (Fiedler et al. 2002). Four culture conditions were prepared, as follows. Equal concentration gradient: culture medium in both top and bottom wells of a Boyden chamber contained $100 \mathrm{ng} / \mathrm{ml}$ rhBMP-2; positive concentration gradient: only the medium in the bottom well contained $100 \mathrm{ng} / \mathrm{ml}$ rhBMP-2; negative concentration gradient: only the medium in the top well contained BMP-2. Absent concentration gradient was the condition in which neither the medium in the top nor the bottom contained $100 \mathrm{ng} / \mathrm{ml}$ rhBMP-2.

\section{Scratch assay}

We assessed the chemokinetic effect of rhBMP-2 using the scratch assay. Rat primary proliferating chondrocytes $\left(2 \times 10^{4}\right.$ cells/well $)$ were seeded into a 6-well plate when the cells reached sub-confluence.
After culturing in DMEM containing 10\% foetal bovine serum (FBS; Sigma, Japan) and antibiotics for $8 \mathrm{~h}$, medium was replaced with the same medium without FBS, then a scratch was gently made with a sterile $200 \mu \mathrm{l}$ pipette tip across the centre of the plate. After two washes with serum free DMEM, the cells were incubated in the same medium in the presence or absence of $10 \mathrm{ng} / \mathrm{ml}$ rhBMP-2. Cell migration into the scratched area was photographed at $0,12,24,36$ and $48 \mathrm{~h}$ and the cell number was counted using NIH image software (NIH, Bethesda, MD) (Katsumoto et al. 2005; Nishio et al. 2005; Zhang et al. 2004).

Preparation of preserved menisci

Preserved menisci were provided by Tutogen Medical Inc. (Neunkirchen, Germany). Menisci were retrieved from cadaveric donors who gave informed consent for cadaveric donations. Donors did not receive any monetary compensation. Donor suitability was established by the medical director in accordance with American Association of Tissue Banks (AATB) standards and Food and Drug Administration (FDA) regulations. Prior to retrieval, a physical examination, medical, social and sexual history inquiry, medical history and medical records review were performed to screen for infections, adverse conditions, risk factors and malignancies. The autopsy report was also checked. Serological tests for infectious diseases were performed.

The retrieved menisci were processed through delipidation, osmotic treatment, oxidation, dehydration and irradiation. Tissue underwent an acetone bath to remove the fat tissues, and the graft was washed in alternating baths of distilled water and saline for osmotic contrast treatment to remove cellular materials. The graft was bathed in hydrogen peroxide washes for oxidative treatment to destroy proteins and immunogenic structures. The graft was then passed through a series of acetone baths for solvent dehydration and viral inactivation to prohibit the growth of microbes and inactivate viruses. Following product packing, the graft was subjected to low-dose gamma irradiation (17-20 kGy). The process required only validated minimal doses of irradiation, thereby preserving the biomechanical integrity of the graft while ensuring post-packaging sterility. 
Evaluation of migrated chondrocytes

within the dense tissues

Supplied menisci with an average pore size of $10 \mu \mathrm{m}$ were punched out perpendicularly to the surface (see Fig. 3 for a representative meniscus) to form a small column. The same culture medium as that used in the scratch test was prepared. Fifty microliters of medium with or without $10 \mathrm{ng} / \mathrm{ml}$ rhBMP-2 was added to the micro-tube. Each piece of meniscus was plugged tightly into a micro-tube so that the bottom of the meniscus was soaked in the solution. Chondrocytes $\left(2 \times 10^{4}\right)$ were then placed on top of the column and cultured for $24 \mathrm{~h}$ in $5 \% \mathrm{CO}_{2}$ at $37^{\circ} \mathrm{C}$.
Following this 24-h incubation, the meniscus columns were washed 3 times with medium to remove rhBMP-2 and non-adherent cells. The cells which had penetrated into the columns were then cultured in DMEM with 10\% FBS and antibiotics for 3 weeks. Paraffin sections were prepared for Hematoxylin-Eosin and Safranin-O staining for histological observation.

Statistical analysis

One-way ANOVA with Tukey's multiple comparison test was used. All tests were two-tailed, with differences considered significant $*$ at $P<0.05$.
Fig. 1 Migratory effect of recombinant human BMP-2 (rhBMP2) on chondrocytes. a Chemotaxis chamber analysis. Increasing concentrations of rhBMP-2 from 0.01 to $10 \mathrm{ng} / \mathrm{ml}$ increased the intensity of fluorescence. However the levels of intensity between 10 and $100 \mathrm{ng} / \mathrm{ml}$ were similar. b Checkerboard analysis. This analysis showed that the migratory effect of rhBMP-2 on chondrocytes was due to chemokinesis
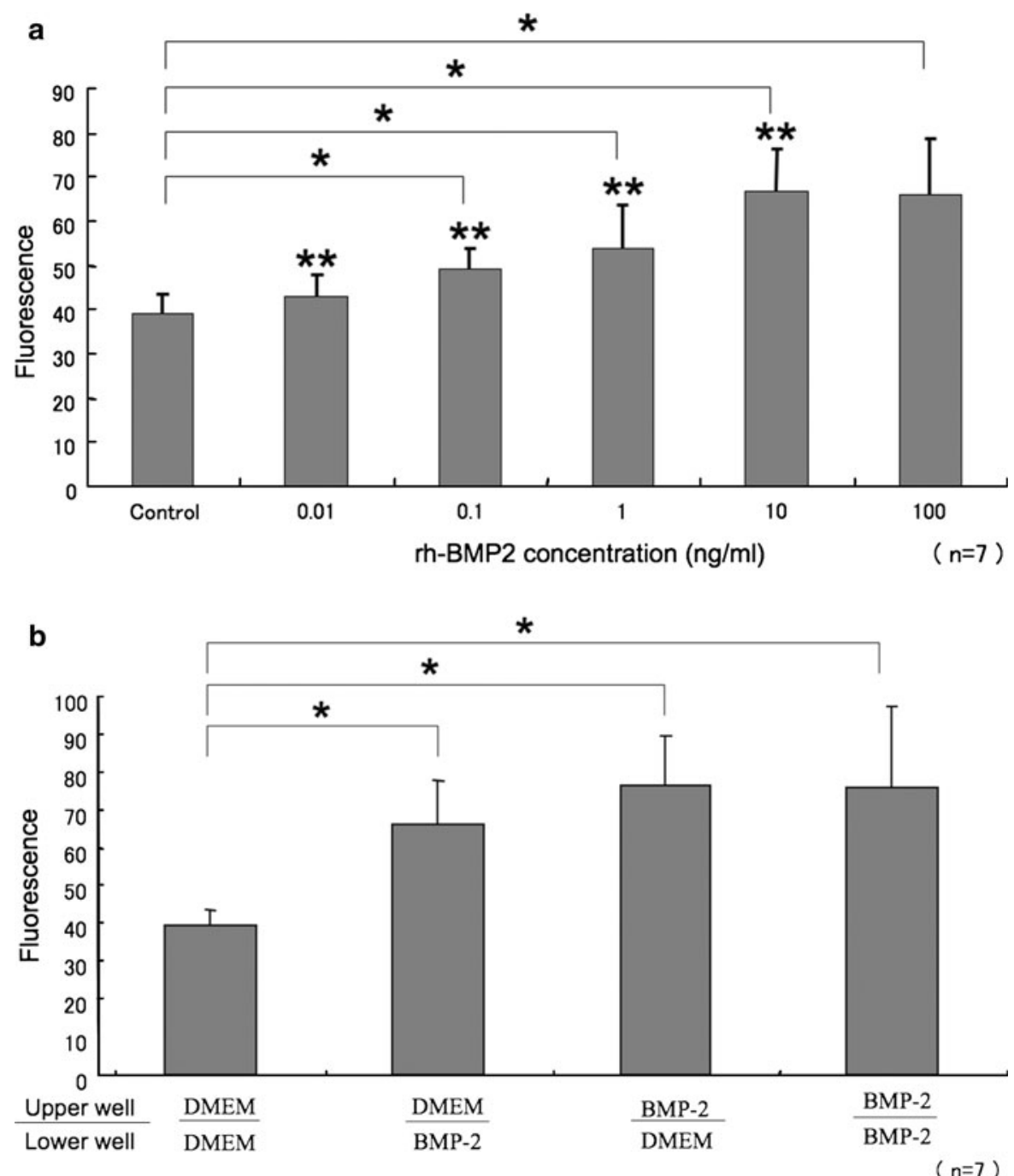


\section{Results}

Migratory response of epiphyseal proliferating chondrocytes to rhBMP-2

The basal numbers of migrated cells in the chemotaxis chambers were in proportion to the numbers of seeded cells (data not shown). The number of migrated cells increased with the addition of rhBMP-2 in a dose dependent manner between 0.01 and $10 \mathrm{ng} / \mathrm{ml}$ (Fig. 1a), and then levelled off above $10 \mathrm{ng} / \mathrm{ml}$. The increments showed a significant difference compared to the control value as depicted in Fig. 1. The numbers of migrated cells in positive, negative and equal concentration gradients were significantly higher than that in the absent concentration gradient, and there
Fig. 2 Scratch assay.

a Percentage of cell migration. Each value was calculated as the percentage of the area covered at each time point divided by the area covered at $48 \mathrm{~h}$ in control. Black and white bars symbolize the percentages of the recombinant human BMP-2 (rhBMP-2) group and control, respectively. A significantly higher migration rate in proportion to time was observed in the rhBMP-2 group when compared to control. b The appearance of the scratched area. The number of migrated cells in the scratched area of a 6-well plate was increased in the rhBMPf-2 group when compared to control. Scale bars represent $100 \mu \mathrm{m}$

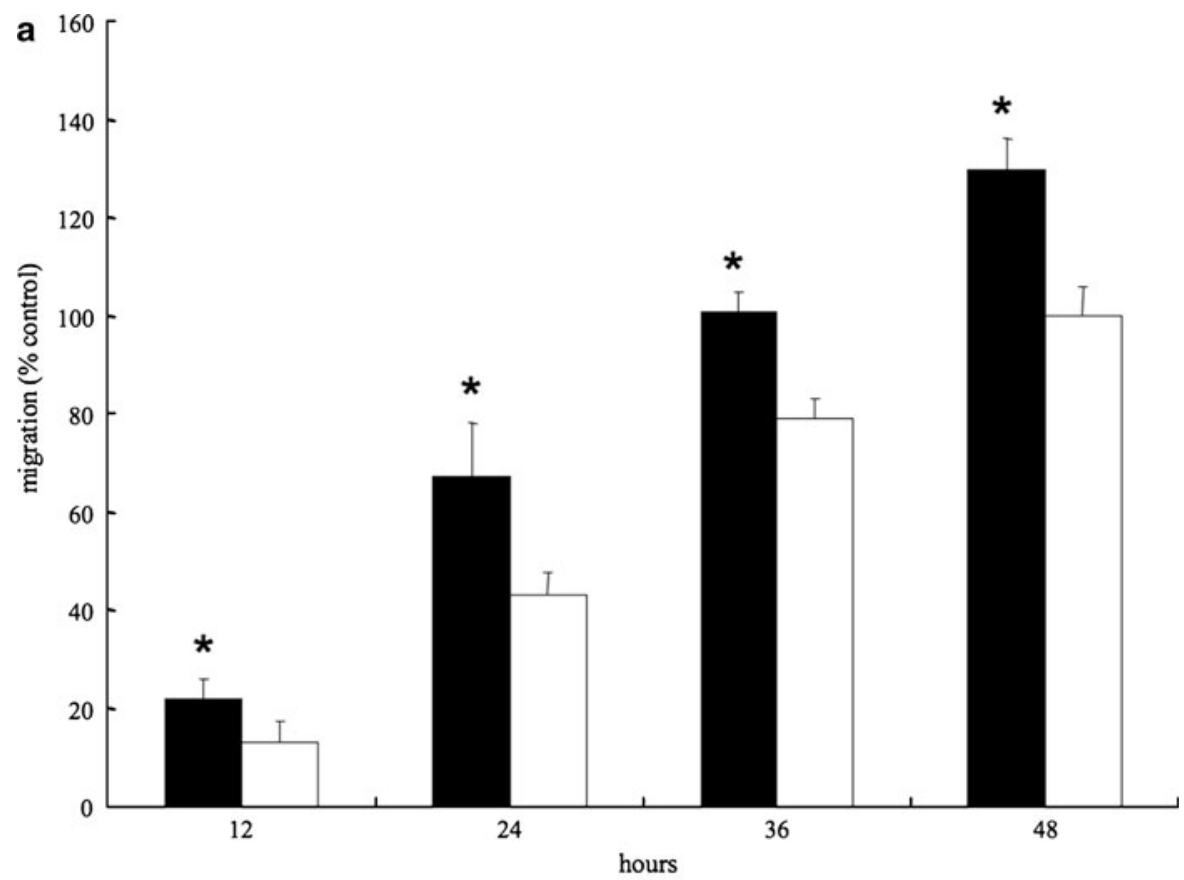

b

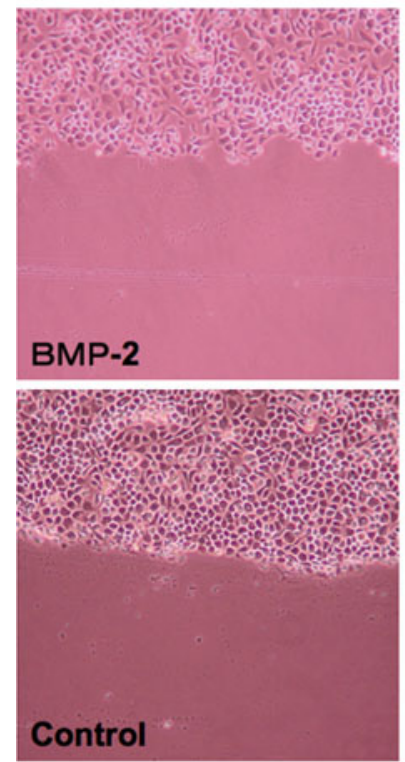

Oh

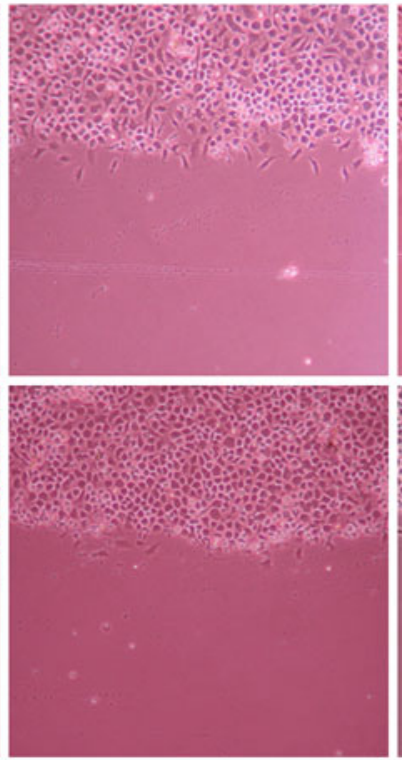

$24 \mathrm{~h}$

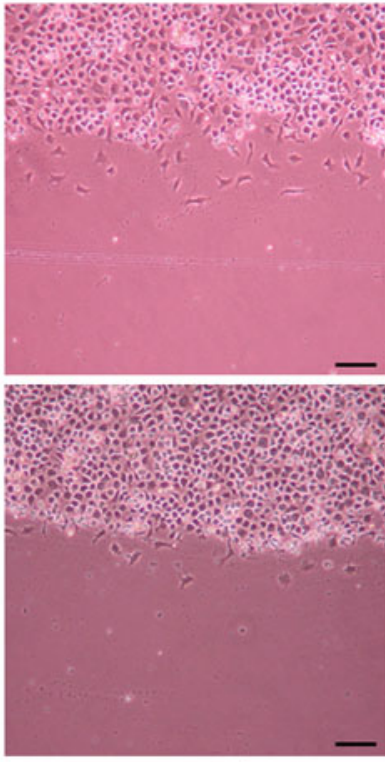

$48 \mathrm{~h}$ 
were no differences between positive, negative and equal concentration gradients (Fig. 1b). The scratch assay showed a significantly higher rate of migration in the rhBMP-2 group at all time points measured (Fig. 2a, b). These results indicate that the effect of rhBMP-2 on chondrocyte migration is not chemotactic but chemokinetic.

Chondrocyte migration into the dense meniscus tissue

Scanning electron microscopy showed that the diameter of the interstitial spaces within the preserved human menisci used for this study was approximately 10-20 $\mu \mathrm{m}$ with the fibrous tissue structure maintained (data not shown). H.E. stained sections of preserved meniscal tissue suggested the homogeneous orientation of collagen fibres and interstitial spaces (Fig. 3b). Both cells and extracellular matrix could be recognized in the meniscus columns cultured for 3 weeks after 24-h rhBMP-2 treatment, but not in the columns cultured without BMP treatment (Fig. 4). In the H.E. stained sections, newly synthesized extracellular matrix was observed between the existing fibrous components (Fig. 4a). This area stained red with Safranin-O (Fig. 4c). The cells and matrix were distributed homogeneously from the tissue surface to the bottom of the column (data not shown). The fibrous structure of the meniscus was either distorted or apparently degraded by the newly formed extracellular matrix (Fig. 4a, c). No cells or newly synthesized extracellular matrix were seen in the control cultures not treated with rhBMP-2 (Fig. 4b, d).

\section{Discussion}

In dense regular connective tissues such as tendons and ligaments, parallel arrays of fibrils and fascicles are uniaxially aligned into cable-like fibrillar structures that maintain the mechanical integrity and strength necessary for their load-bearing function. Many investigators are currently studying the use of decellularized tissue allografts from human cadavers
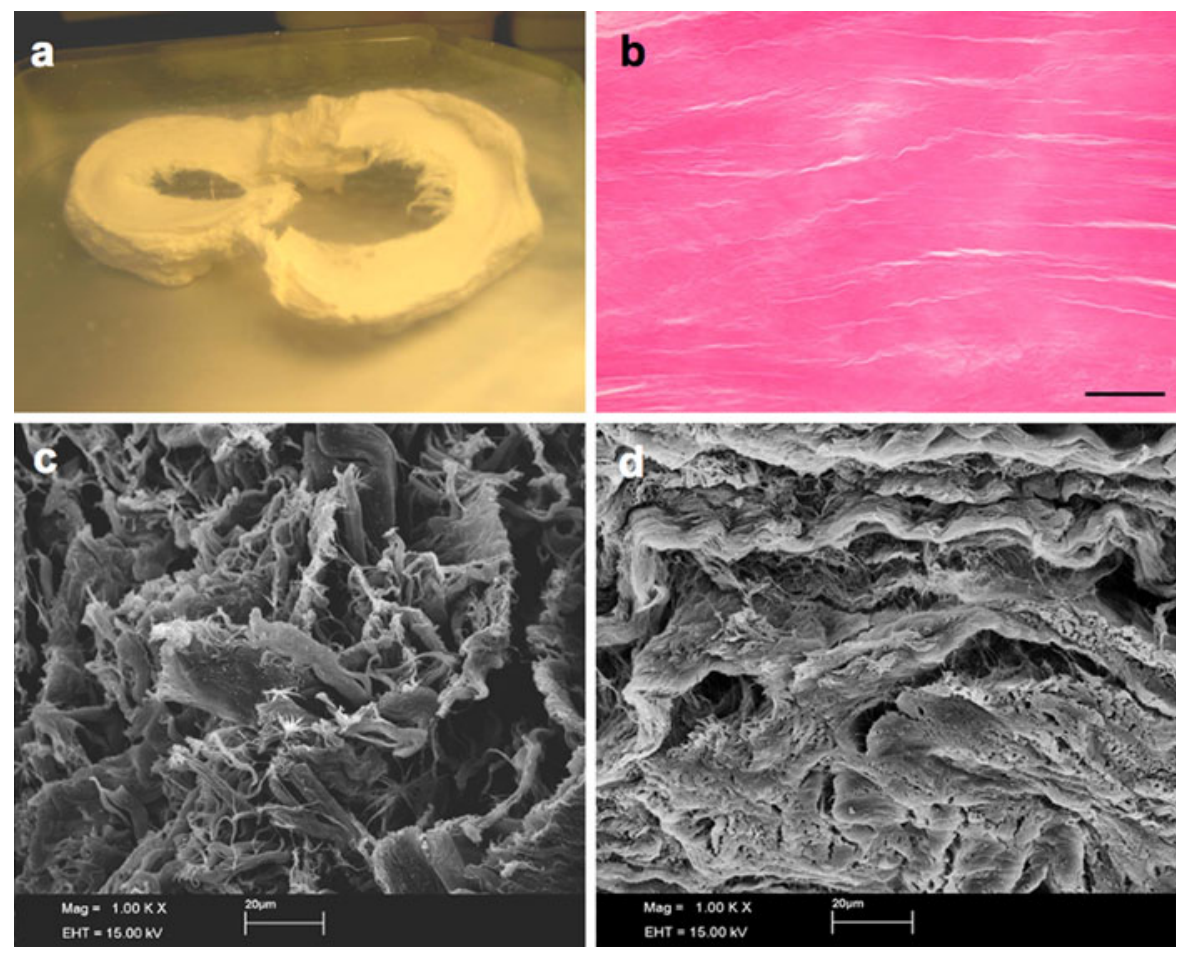

Fig. 3 Evaluation of solvent preserved meniscus from human cadavers. a Gross appearance of solvent preserved meniscus. The meniscus was punched out perpendicularly to the surface to form a small column. b H.E. stained section of preserved

meniscus. No cells were evident and collagen fibers were homogeneously stained with eosin. Scale bars represent $100 \mu \mathrm{m}$ 

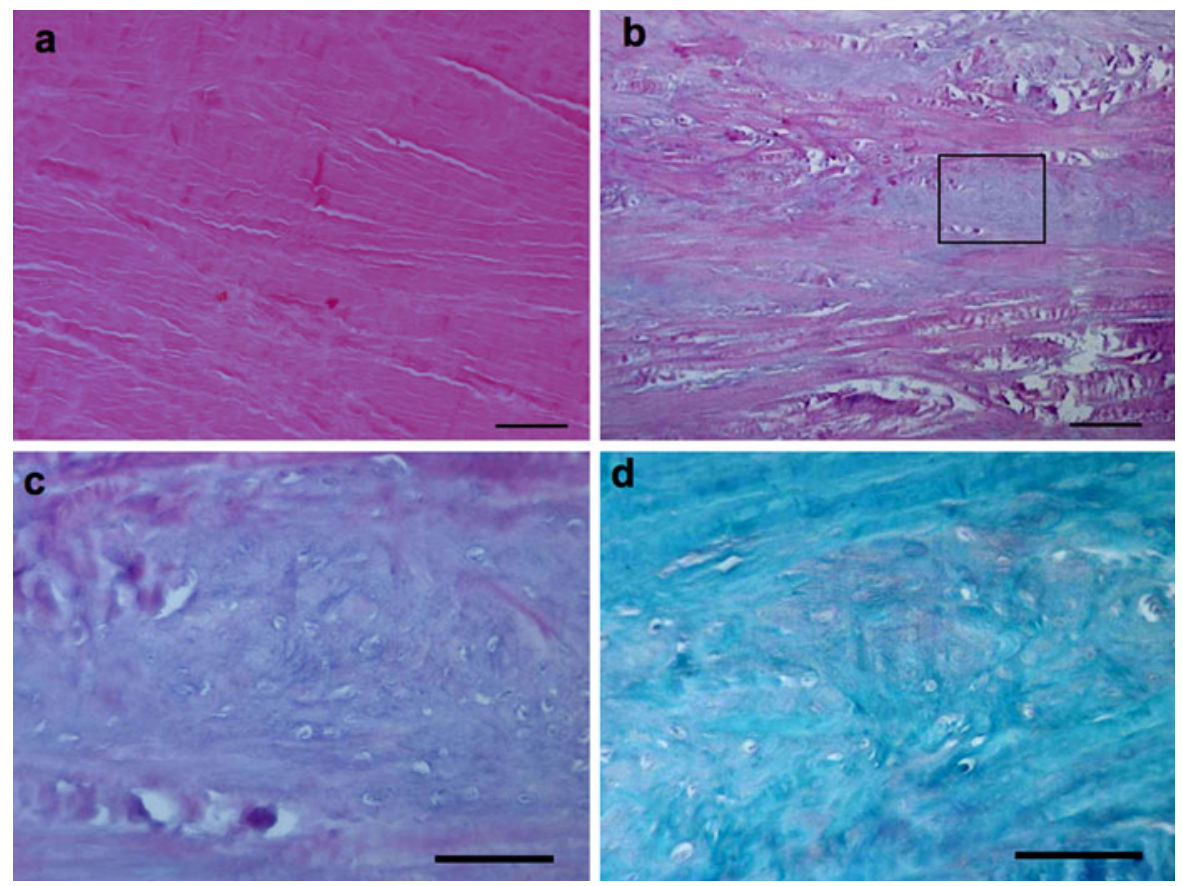

Fig. 4 Histology of migrated chondrocytes within the dense tissue. a H.E. stained section of solvent preserved meniscus with recombinant human BMP-2 (rhBMP-2). Migrated chondrocytes and newly-formed extracellular matrix were observed in H.E stained sections. High $(\times 400)$ magnification is shown below right. b H.E. stained section of solvent preserved meniscus without rhBMP-2 as a control. c Safranin O stained

as scaffolds onto which patients' cells could be seeded, or as carriers for transplantation of genetically engineered cells. However, it is difficult to seed cells into high density regular connective tissue which has few interstitial spaces.

We turned our attention to cancer cells to solve the difficulty of cell induction into these connective tissues. Cancer cell migration is critical in the invasive growth of cancer into the connective tissues (Albini et al. 1987). Various growth factors and cytokines are involved in cellular infiltration into the narrow interstitial spaces in a relatively short time (Zigmond and Hirsch 1972). The purpose of this study was to investigate the potential of chondrocytes to infiltrate into dense meniscus tissue in relation to the chemotactic/chemokinetic effect of BMP-2.

BMP-2 has been reported to induce migration of bone marrow derived undifferentiated mesenchymal stem cells, osteoblasts, fibroblasts and cells derived from menisci. Although chondrocyte differentiation by BMP-2 has been well studied (Erickson et al. section of solvent preserved meniscus with rhBMP-2. Migrated chondrocytes and newly-formed extracellular matrix were observed in Safranin O stained sections. High $(\times 400)$ magnification is shown below right. d Safranin O stained section of solvent preserved meniscus without rhBMP-2 as a control

1997), the migration response of chondrocytes to BMP-2 has not been investigated. Our results indicate that rhBMP-2 has a chemokinetic effect on chondrocytes. The optimal concentration, $10 \mathrm{ng} / \mathrm{ml}$, for chondrocyte migration is one fifth of that required for induction of cellular differentiation (Erickson et al. 1997). Within the tissue, the local concentration of BMP-2 is predicted to gradually decrease in relation to the distance from the site where the cytokine is synthesized. Thus cell migration may be induced at sites distant from BMP-2 synthesizing cells, while cell differentiation may be induced at sites close to these cells.

We have shown that chondrocytes migrate deeply into the preserved meniscal tissues if induced by BMP-2. Characteristics of the scaffold such as pore size, shape, interconnectivity, and material stiffness or surface chemistry and degradability influence tissue regeneration. Of note, the scaffold pore size is highly related to the proliferation and differentiation of chondrocytes in culture (Bhardwaj et al. 2001; Malda 
et al. 2005; Nehrer et al. 1997; Yamane et al. 2007). In our study, we show that BMP-2 induces chondrocyte migration and proteoglycan production throughout the meniscus tissue in vitro. By combining appropriate scaffolds with application of a low concentration of BMP-2, effective application of chemokinesis to cartilage tissue engineering is expected even with seeding of a small number of recipient cells.

Acknowledgments We thank M. Ohashi, M. Kuranaga and Y. Matsui for their technical assistance. This investigation was supported in part by grants-in-aid from the Ministry of Science, Education and Culture of Japan, by grants-in-aid from the Ministry of Health, Labor and Welfare for the Research on Human Genome, Tissue Engineering and Food Biotechnology, to M. I., by grants-in-aid from the Ministry of Science, Education and Culture of Japan to K. N. and K. U., and by research grants from Parents' Association of Kitasato University School of Medicine, Nakatomi Foundation and SDS Inc. to K. N. Part of this study was supported by a grant for scientific research from the Postgraduate Research Project No. 3051, 3076 and 3094 at Graduate School of Medical Science, Kitasato University to K. U. Part of this study was also supported by Private Universities Grant for Promotion of Fundamental Strategic Research to M.I.

Open Access This article is distributed under the terms of the Creative Commons Attribution Noncommercial License which permits any noncommercial use, distribution, and reproduction in any medium, provided the original author(s) and source are credited.

\section{References}

Albini A, Iwamoto Y, Kleinman HK, Martin GR, Aaronson SA, Kozlowski JM, McEwan RN (1987) A rapid in vitro assay for quantitating the invasive potential of tumor cells. Cancer Res 47:3239-3245

Bhardwaj T, Pilliar RM, Grynpas MD, Kandel RA (2001) Effect of material geometry on cartilagenous tissue formation in vitro. J Biomed Mater Res 57:190-199. doi: 10.1002/1097-4636(200111)57:2

Bhargava MM, Attia ET, Murrell GA, Dolan MM, Warren RF, Hannafin JA (1999) The effect of cytokines on the proliferation and migration of bovine meniscal cells. Am J Sports Med 27:636-643

Chen P, Carrington JL, Hammonds RG, Reddi AH (1991a) Stimulation of chondrogenesis in limb bud mesoderm cells by recombinant human bone morphogenetic protein 2B (BMP-2B) and modulation by transforming growth factor beta 1 and beta 2. Exp Cell Res 195:509-515

Chen TL, Bates RL, Dudley A, Hammonds RG Jr, Amento EP (1991b) Bone morphogenetic protein-2b stimulation of growth and osteogenic phenotypes in rat osteoblast-like cells: comparison with TGF-beta 1. J Bone Miner Res 6:1387-1393
Cimetta E, Flaibani M, Mella M, Serena E, Boldrin L, De Coppi P, Elvassore N (2007) Enhancement of viability of muscle precursor cells on $3 \mathrm{D}$ scaffold in a perfusion bioreactor. Int J Artif Organs 30:415-428

Date T, Doiguchi Y, Nobuta M, Shindo H (2004) Bone morphogenetic protein-2 induces differentiation of multipotent C3H10T1/2 cells into osteoblasts, chondrocytes, and adipocytes in vivo and in vitro. J Orthop Sci 9:503-508. doi:10.1253/circj.69.1547

Erickson DM, Harris SE, Dean DD, Harris MA, Wozney JM, Boyan BD, Schwartz Z (1997) Recombinant bone morphogenetic protein (BMP)-2 regulates costochondral growth plate chondrocytes and induces expression of BMP-2 and BMP-4 in a cell maturation-dependent manner. J Orthop Res 15:371-380

Fiedler J, Roderer G, Gunther KP, Brenner RE (2002) BMP-2, BMP-4, and PDGF-bb stimulate chemotactic migration of primary human mesenchymal progenitor cells. J Cell Biochem 87:305-312

Griffon DJ, Sedighi MR, Sendemir-Urkmez A, Stewart AA, Jamison R (2005) Evaluation of vacuum and dynamic cell seeding of polyglycolic acid and chitosan scaffolds for cartilage engineering. Am J Vet Res 66:599-605

Holy CE, Shoichet MS, Davies JE (2000) Engineering threedimensional bone tissue in vitro using biodegradable scaffolds: investigating initial cell-seeding density and culture period. J Biomed Mater Res 51:376-382. doi: 10.1002/1097-4636(20000905)51:3

Katsumoto M, Shingu T, Kuwashima R, Nakata A, Nomura S, Chayama K (2005) Biphasic effect of HMG-CoA reductase inhibitor, pitavastatin, on vascular endothelial cells and angiogenesis. Circ J 69:1547-1555. doi:10.1253/circj. 69.1547

Kawasaki K, Aihara M, Honmo J, Sakurai S, Fujimaki Y, Sakamoto K, Fujimaki E, Wozney JM, Yamaguchi A (1998) Effects of recombinant human bone morphogenetic protein-2 on differentiation of cells isolated from human bone, muscle, and skin. Bone 23:223-231

Langer R (2000) Tissue engineering. Mol Ther 1:12-15

Lind M, Eriksen EF, Bunger C (1996) Bone morphogenetic protein- 2 but not bone morphogenetic protein- 4 and -6 stimulates chemotactic migration of human osteoblasts, human marrow osteoblasts, and U2-OS cells. Bone 18: 53-57. doi:10.1016/8756-3282(95)00423-8

Malda J, Woodfield TB, van d Wilson VC, Martens DE, Tramper J, van Blitterswijk CA, Riesle J (2005) The effect of PEGT/PBT scaffold architecture on the composition of tissue engineered cartilage. Biomaterials 26 : 63-72. doi:10.1016/j.biomaterials.2004.02.046

Massague J (1992) Receptors for the TGF-beta family. Cell 69:1067-1070. doi:10.1016/0092-8674(92)90627-O

Mauck RL, Seyhan SL, Ateshian GA, Hung CT (2002) Influence of seeding density and dynamic deformational loading on the developing structure/function relationships of chondrocyte-seeded agarose hydrogels. Ann Biomed Eng 30:1046-1056. doi:10.1114/1.1512676

Mukaida T, Urabe K, Naruse K, Aikawa J, Katano M, Hyon SH, Itoman M (2005) Influence of three-dimensional culture in a type II collagen sponge on primary cultured and dedifferentiated chondrocytes. J Orthop Sci 10:521-528. doi: 10.1007/s00776-005-0930-8 
Nehrer S, Breinan HA, Ramappa A, Shortkroff S, Young G, Minas T, Sledge CB, Yannas IV, Spector M (1997) Canine chondrocytes seeded in type I and type II collagen implants investigated in vitro. J Biomed Mater Res 38: 95-104

Nishio T, Kawaguchi S, Yamamoto M, Iseda T, Kawasaki T, Hase $\mathrm{T}$ (2005) Tenascin-C regulates proliferation and migration of cultured astrocytes in a scratch wound assay. Neuroscience 132:87-102. doi:10.1016/j.neuroscience. 2004.12.028

Ryoo HM, Lee MH, Kim YJ (2006) Critical molecular switches involved in BMP-2-induced osteogenic differentiation of mesenchymal cells. Gene 366:51-57. doi: 10.1016/j.gene.2005.10.011

Sampath TK, Coughlin JE, Whetstone RM, Banach D, Corbett C, Ridge RJ, Ozkaynak E, Oppermann H, Rueger DC (1990) Bovine osteogenic protein is composed of dimers of OP-1 and BMP-2A, two members of the transforming growth factor-beta superfamily. J Biol Chem 265:13198-13205

Sekiya I, Larson BL, Vuoristo JT, Reger RL, Prockop DJ (2005) Comparison of effect of BMP-2, -4, and -6 on in vitro cartilage formation of human adult stem cells from bone marrow stroma. Cell Tissue Res 320:269-276. doi: 10.1007/s00441-004-1075-3

Solchaga LA, Tognana E, Penick K, Baskaran H, Goldberg VM, Caplan AI, Welter JF (2006) A rapid seeding technique for the assembly of large cell/scaffold composite constructs. Tissue Eng 12:1851-1863

Stewart MC, Kadlcek RM, Robbins PD, MacLeod JN, Ballock RT (2004) Expression and activity of the CDK inhibitor p57Kip2 in chondrocytes undergoing hypertrophic differentiation. J Bone Miner Res 19:123-132

Thevenot P, Nair A, Dey J, Yang Jian, Tang L (2008) Method to analyze three-dimensional cell distribution and infiltration in degradable scaffolds. Tissue Eng Part C Methods 14:319-331. doi:10.1089/ten.tea.2008.0221

Timmins NE, Scherberich A, Fruh JA, Heberer M, Martin I, Jakob M (2007) Three-dimensional cell culture and tissue engineering in a T-CUP (tissue culture under perfusion). Tissue Eng 13:2021-2028. doi:10.1089/ten.2006.0158

Uchida K, Urabe K, Naruse K, Ujihira M, Mabuchi K, Itoman M (2007) Comparison of the cytokine-induced migratory response between primary and subcultured populations of rat mesenchymal bone marrow cells. J Orthop Sci 12: 484-492. doi:10.1007/s00776-007-1159-5

Wendt D, Marsano A, Jakob M, Heberer M, Martin I (2003) Oscillating perfusion of cell suspensions through threedimensional scaffolds enhances cell seeding efficiency and uniformity. Biotechnol Bioeng 84:205-214. doi:10.1002/ bit.10759

Wozney JM, Rosen V, Celeste AJ, Mitsock LM, Whitters MJ, Kriz RW, Hewick RM, Wang EA (1988) Novel regulators of bone formation: molecular clones and activities. Science 242:1528-1534. doi:10.1126/science.3201241

Yamane S, Iwasaki N, Kasahara Y, Harada K, Majima T, Monde K, Nishimura S, Minami A (2007) Effect of pore size on in vitro cartilage formation using chitosan-based hyaluronic acid hybrid polymer fibers. J Biomed Mater Res A 81:586-593. doi:10.1002/jbm.a.31095

Zhang M, Zhang X, Bai CX, Chen J, Wei MQ (2004) Inhibition of epidermal growth factor receptor expression by RNA interference in A549 cells. Acta Pharmacol Sin 25:61-67

Zigmond SH, Hirsch JG (1972) Effects of cytochalasin B on polymorphonuclear leucocyte locomotion, phagocytosis and glycolysis. Exp Cell Res 73:383-393 